\title{
The Effect of Irrigation Intervals on the Growth and Yield of Quinoa Crop and Its Components
}

\author{
Abdullah M. Algosaibi ${ }^{1}$, Ayman E. Badran ${ }^{2}$,Abdulrahman M. Almadini ${ }^{1} \&$ Mohammed M. El-Garawany $^{3}$ \\ ${ }^{1}$ Agricultural Environment \& Natural Resources Department, College of Agriculture \& Food Sciences, King \\ Faisal University, Saudi Arabia \\ ${ }^{2}$ Genetic Resources Department, Desert Research Center, Cairo, Egypt \\ ${ }^{3}$ Agricultral \& Veterinary Research \& Training Station, King Faisal University, Saudi Arabia \\ Correspondence: Ayman E. Badran, Genetic Resources Department, Desert Research Center, Cairo, Egypt. \\ E-mail: dr.ayman_badran@yahoo.com
}

Received: April 23, 2017

doi:10.5539/jas.v9n9p182

\author{
Accepted: June 26, $2017 \quad$ Online Published: August 15, 2017 \\ URL: https://doi.org/10.5539/jas.v9n9p182
}

\begin{abstract}
This experiment was conducted to study the effect of irrigation intervals on growth, yield and its components and some of the chemical characteristics of the soil after the harvest of quinoa (Chenopodium quinoa willd) plant. Three treatments were used as follow: T1 (twice irrigation every week, which is the common in the region), T2 (once irrigation every week) and T3 (twice irrigation every two weeks) using in a randomized complete block design with four replicates. The crop coefficient $(\mathrm{Kc})$ value differed according to the stage of growth where the results showed that the $\mathrm{T} 2$ treatment gave the highest mean in all the studied traits followed by the T3 treatment in all traits except the number of seed $/ \mathrm{m}^{2}$. The results also confirmed that the increase in water reduced the agronomic traits such as harvest index, number of seeds and yield of seeds and straw $/ \mathrm{m}^{2}$. Also it showed that the $\mathrm{pH}$ values in soils were not significantly affected by irrigation, while Ec significantly affected. Correlation coefficient was negative with the most traits and low with the number of grain $(0.34)$ under overall studied treatments which confirms that quinoa is a plant that needs limited amounts of irrigation water. On the other hand there was positive strong correlation between the harvest index and grain yield (0.92). The results showed that moisture stress treatments increased the concentration of the ionic, $\mathrm{NH}_{4}-\mathrm{N}$ and $\mathrm{NO}_{3}-\mathrm{N}$ significantly compared to soils which do not have moisture stress (T1, T2). We assume that the development based on Kc during growth-stages helps in irrigation management and provides precise water applications for quinoa plant. These results indicate that the water requirements of quinoa plant are limited and that quinoa plant growth is not affected by the lack of irrigation water on the crop and its qualities.
\end{abstract}

Keywords: Chenopodium, moisture stress, Kc, correlation coefficient

\section{Introduction}

Water availability is one of the most important specific factors of crops production. Therefore, the irrigation intervals are considered one of the strategies used to enhancing irrigation water use efficiency. In order to maintain a sustainable agriculture we must focus on the study of plant response to lack of water and rationing of irrigation water, especially in the scope of arid regions of the world. The world is facing a growing steadily in population, which requires increasing in agricultural production to meet the food shortage (Howell, 2001). Sustainable farming systems become a key element in developing strategies to optimize the use of water for crop production and to introduce effective water management practices (Smith, 2000; Howell, 2001; Kijne et al., 2003). So, specialists have resorted to what is called deficit irrigation for resolve this problem of food security using the least amount of irrigation water. Generally, low yields are very often reported due to drought stress (Bilbao Lopez et al., 2006). Quinoa plant is considered from the species that are resistant to various stresses such as salinity, cold air, high solar radiation, low temperature and different $\mathrm{pH}$ in the soil (Jacobsen et al., 1998). It can also grow in arid and semi-arid regions (Jacobsen et al., 1994). While, both the Gallardo and Gonzalez (1992) explained that the soil moisture level plays an important role in determining the time and the growth rate of quinoa seeds and seedlings. Symptoms of moisture stress, whether drought or water logging lead to a decrease in photosynthesis, protein degradation, stomatal closure and the decreasing in respiration rates and biomass production and also determining the global geographic distribution of vegetation and restriction of crop yields in 
agriculture (Lin et al., 2006; Henriques, 2008). Nutrients in the soil under drought stress may be available for the plant (McDonald \& Davis, 1996), but the potential benefit from it often is questionable as a result of the weakness of the plant's ability to absorb those elements. Also, drought stress has been associated with osmotic adjustment in the cells using accumulation of different compounds such as soluble sugars, proline, polyols, and other organic compounds (Chai et al., 2001). Previous studies have shown that the quinoa plant has several mechanisms to resist drought (Jensen et al., 2000; Jacobsen et al., 2003b). Therefore, the cultivation of quinoa in prefers of scarce water resources regions which is prevalent in many areas. As a result of the scarcity of water resources, the full irrigation is not a a strategic option. However, the restriction of the addition of water in the stages of crop growth can lead to a significant increase in yield (Garcia et al., 2003). In areas where water is the most limiting factor, maximizing water productivity may be economically more profitable for the farmer than maximizing yields (English, 1990). In other words, deficit irrigation aims at stabilizing yields and at obtaining maximum water productivity rather than maximum yields (Zhang \& Oweis, 1999). Geerts et al. (2006) showed that, deficit irrigation is a valuable option for yield stabilization of quinoa plant in various areas of Bolivian Altiplano, where intra-seasonal dry periods are of great importance. Quinoa thus represents an invaluable opportunity, both as a potential crop in consideration of present and future climate change challenges Razzaghi et al. (2012). Correlation studies between characters are very important in plant breeding for indirect selection and have also been of great value in the determination of the most effective breeding procedures (Badran et al., 2015).

In the present paper, the aim of this study was to evaluate the effect of drought stress on the quinoa crop as introduction of breeding program for the balancing between soil moisture and transpiration.

\section{Materials and Methods}

\subsection{Plant Material and Experimental Conditions}

The investigation was conducted to evaluate the effect of irrigation intervals on the growth, yield and its components of C. quinoa willd (Chipaya cv.) plant during 2016/2017 season. The seeds obtained from Desert Research Center, Cairo, Egypt and the experiment was conducted in Training and Research Station of Agricultural and Veterinary of King Faisal University, Al-Ahsa, Saudi Arabia. Three treatments were used as follows: 1) the first treatment (T1): the flood irrigation two times every week (common use); 2) the second treatment (T2): the flood irrigation one time every week; 3 ) the third treatment (T3): the flood irrigation one time every two weeks. The experiment was set up in a randomized complete block design with four replicates .The plant density was at 30 plants per square meter where experimental lot area was $3 \times 4 \mathrm{~m}^{2}$ and the spacing between each treatment and the other was $3 \times 4 \mathrm{~m}^{2}$.

The meteorological aspects during periods of growth of quinoa plants obtained from "the Meteorological Authority" located in the eastern part of Saudi Arabia in the Al Hasa Oasis. The study area is located between latitudes $25^{\circ} 16^{\prime} 14^{\prime \prime}$ and $25^{\circ} 15^{\prime} 25^{\prime \prime}$ North and $49^{\circ} 43^{\prime} 49^{\prime \prime}$ and $49^{\circ} 41^{\prime} 42^{\prime \prime}$ East and rises from the sea about $150 \mathrm{~m}$ i.e. under dry tropical climate.

\subsection{Analysis of Soil Characteristics and Irrigation Water}

Soil samples were assembling before planting and collected in plastic bags at a depth ranging from 0 to $30 \mathrm{~cm}$. Then, the physical properties were done by the international pipette methods (Black, 1965) and chemical analyses were performed on saturated paste extract according to procedures outlined by Page et al. (1982) (Table 1A). Also, the total nitrogen, available phosphorus and potassium were measured. In the same manner, the irrigation water samples were collected to assess it as shown in Table (1B). 
Table 1A. Physical and chemical properties of used soil samples before sowing

\begin{tabular}{|c|c|c|c|c|c|}
\hline Particle distribution & Value & Soluble ions $\left(\mathrm{mmol} \mathrm{L}^{-1}\right)$ & Value & Nutrients available $\left(\mathrm{mg} \mathrm{kg}^{-1}\right)$ & Value \\
\hline Fine sand $(\%)$ & 45.2 & $\mathrm{Na}^{+}$ & 5.24 & Total N & 42.4 \\
\hline Coarse sand (\%) & 35.4 & $\mathrm{~K}^{+}$ & 5.87 & Extractable $(\mathrm{K})$ & 4.5 \\
\hline Silt (\%) & 15.2 & $\mathrm{Ca}^{++}$ & 2.15 & Extractable $(\mathrm{P})$ & 200 \\
\hline Clay $(\%)$ & 4.2 & $\mathrm{Mg}^{++}$ & 0.65 & & \\
\hline Texture Class & Sandy silt & $\mathrm{CO}_{3}^{--}$ & - & & \\
\hline Saturation $(\%)$ & 18.2 & $\mathrm{HCO}_{3}^{-}$ & 1.57 & & \\
\hline $\mathrm{EC}\left(\mathrm{dSm}^{-1}\right)$ & 2.02 & $\mathrm{Cl}^{-}$ & 6.32 & & \\
\hline $\mathrm{pH}$ & 7.2 & $\mathrm{SO}_{4}^{--}$ & 6.71 & & \\
\hline Organic matter $(\%)$ & 30.2 & & & & \\
\hline
\end{tabular}

The $\mathrm{pH}$ and $\mathrm{EC}$ were determined in saturated soil paste extraction. $\mathrm{CaCO}_{3}$ and texture estimated according to Black (1965).

Table 1B. Chemical composition, EC and $\mathrm{pH}$ of irrigation water used

\begin{tabular}{|c|c|c|c|c|c|c|c|c|c|}
\hline \multirow{2}{*}{$\mathrm{pH}$} & \multirow{2}{*}{$\mathrm{EC}\left(\mathrm{dSm}^{-1}\right)$} & \multicolumn{4}{|c|}{ Soluble cations meq/L } & \multicolumn{4}{|c|}{ Soluble anions meq/L } \\
\hline & & $\mathrm{Na}^{+}$ & $\mathrm{K}^{+}$ & $\mathrm{Ca}^{++}$ & $\mathrm{Mg}^{++}$ & $\mathrm{CO}_{3}^{--}$ & $\mathrm{HCO}_{3}^{-}$ & $\mathrm{Cl}^{-}$ & $\mathrm{SO}_{4}^{--}$ \\
\hline 6.96 & 1.95 & 7.27 & 5.43 & 2.86 & 1.01 & - & 2.68 & 8.40 & 2.02 \\
\hline
\end{tabular}

\subsection{Agricultural Practices}

Compound fertilizer N-P-K (20:20:20) at the rate of $50 \mathrm{~kg} \mathrm{ha}^{-1}$ according to Choukr-Allah et al. (2016), used in three phases; the first dose before sowing, and the second dose after the emergence of the fourth leaf (after 25 days from sowing), and the third dose before the emergence of the inflorescence (after 60 days from sowing) and also has been manually weed control.

\subsection{Measurements}

\section{1) Grain Yield}

The seed of all the plants of each square meter were bulked after threshing by a stationary thresher and weighed using a proper balance and the grain yield $/ \mathrm{m}^{2}$ was converted to mega gram per hectare. Straw yield was collected after the threshing process and then it was weighed. Harvest index \% (HI) which was calculated by the following formula: $\mathrm{HI}=\left(\right.$ grain yield plant $\left.{ }^{-1}\right) /\left(\right.$ dry weight plant $\left.^{-1}\right)$. Number of grain $\mathrm{m}^{2} \times 10^{3}$ calculated after collecting the seeds of plants per square meter and counting them manually.

2) Electrical Conductivity $\left(\mathrm{EC}\left(\mathrm{dSm}^{-1}\right)\right)$

$\mathrm{pH}$ and the concentration of some elements in the soil under the three treatments after harvest.

\section{3) Crop Water Requirements}

The following equations were used to calculate standard evapo-transpiration (ETo) using mean temperature $\left({ }^{\circ} \mathrm{C}\right)$; mean relative humidity (RH in \%); wind speed ( $\mathrm{m} / \mathrm{sec}$ at $2 \mathrm{~m}$ height) and mean sunshine duration (hour/day) given by the modified Penman formula for "Reference evapo-transpiration" (ETo) (FAO, 1984) as follow:

$$
E T o=c \cdot W \cdot R n+(1-W) \cdot f(U) \cdot(e a-e d)
$$

Where, $(e a-e d)=$ vapor pressure deficit which is the difference between saturation vapor pressure (ea) at $\mathrm{T}$ mean in $\mathrm{m}$ bar and actual vapor pressure (ed) in $\mathrm{m}$ bar; $f(U)=$ wind function of $f(U)=0.27 \cdot(1+U / 100)$ with $U$ in $\mathrm{Km} /$ day measured at $2 \mathrm{~m}$ height; $R n=$ total net radiation in $\mathrm{mm} /$ day; $W=$ temperature and altitude dependent weighting factor; $c=$ adjustment factor for ratio $U$ day $/ U$ night.

The account of evapo-transpiration carried of comparative crop from the equation Penman modified depending on temperatures, humidity, speed wind information and sunshine duration through the monitoring station of study area. The program issued by International Food and Agriculture Organization and the No. 24 in 1984 is used and the following equation was used to calculate the net irrigation requirements:

Crop water requirements (ETcrop) $=$ Crop coefficient $(K c) \times$ Reference evapotranspiration (ETo)

Where, $K_{c}=K_{c b}+K_{e}$, basal crop coefficient $\left(K_{c b}\right)$ and evaporation coefficient $\left(K_{e}\right)$ were determined according to (Allen et al., 1998). 
The crop growing season has been divided into four stages and crop coefficient values are different depending on the crop and different growth stages of reference crop.where, in the first stage (early growth) the crop covered less than $10 \%$ of the land and the second stage (crop growth) began from the first phase and until the arrival of the crop to the almost complete coverage of the soil. The third stage (middle season growth stage) and which started from the end of the second stage until the beginning of maturity. The fourth stage (the end of season) from the end of mid-season stage until full maturity or harvest. Also, the amount of irrigation water added calculated in the case of surface irrigation from the following equation:

$$
A W=E a /(1-L R)
$$

Where, $A W$ : irrigation water depth (mm/day); $L R$ : Leaching requirements as a fraction $(20 \%)$ of surface irrigation; $E a$ : Efficient of irrigation water are included as a fraction $(60 \%)$ of the net irrigation requirements and which calculate as follow:

$$
E a=G Y / A W
$$

Where, $G Y$ : Grain yield (ha/ $\mathrm{kg}) ; A W$ : the amount of irrigation water added $\left(\mathrm{m}^{3} / \mathrm{ha}\right)$.

\subsection{Statistical Analysis and Correlation Coefficient}

For means comparison, LSD values were calculated following the method of Steel and Torrie (1989) using SAS program. Statistical analyses for all studied traits were done following Singh and Chaudhary (1995) for correlation coefficient.

\section{Results}

During the course of the study (December to March) the mean of temperatures is $17.77^{\circ} \mathrm{C}$ during the periods of winter season. The general minimum average of temperature is about $5.74{ }^{\circ} \mathrm{C}$ during season while the average maximum was $32.98{ }^{\circ} \mathrm{C}$. According to, the relative humidity had a minimum mean value of $31.15 \%$ which was recorded in March and highest mean relative humidity was recorded in January with a value of $60.05 \%$. It is known that the rainfall is ranging from a rare to nonexistent in area of study where, the rainfall data during the experiment periods shows zero value as average during all tested months except in January was recorded 0.04 $\mathrm{mm}$ as average during the month data. The mean values of the wind speed shows a gradual increase from 1.96 $\mathrm{ms}^{-1}$ in the first stage (December) until the end stage $\left(3.2 \mathrm{~m} \mathrm{~s}^{-1}\right)$. While, the average value of actual hours of sunshine was recorded in December $(8.5 \mathrm{~h} /$ day) during the different growth stages (Table 2).

\begin{tabular}{|c|c|c|c|c|c|}
\hline Month & Temperature $\left({ }^{\circ} \mathrm{C}\right)$ & Humidity (\%) & Wind speed $\left(\mathrm{ms}^{-1}\right)$ & Sunshine (h/day) & $\begin{array}{l}\text { Average of rain-fall } \\
(\mathrm{mm})\end{array}$ \\
\hline \multicolumn{6}{|l|}{ December } \\
\hline Mean & 16.21 & 34.54 & 1.96 & 8.5 & 0.00 \\
\hline Maximum & 30.74 & 97.10 & 10.80 & & 0.10 \\
\hline Minimum & 3.74 & 8.51 & 0.00 & & 0.00 \\
\hline \multicolumn{6}{|l|}{ January } \\
\hline Mean & 15.50 & 60.05 & 2.15 & 6.3 & 0.04 \\
\hline Maximum & 27.97 & 96.90 & 8.17 & & 3.60 \\
\hline Minimum & 4.40 & 20.27 & 0.00 & & 0.00 \\
\hline \multicolumn{6}{|l|}{ February } \\
\hline Mean & 17.89 & 43.69 & 3.02 & 8.0 & 0.00 \\
\hline Maximum & 34.11 & 93.00 & 9.49 & & 0.30 \\
\hline Minimum & 5.32 & 11.37 & 0.00 & & 0.00 \\
\hline \multicolumn{6}{|l|}{ March } \\
\hline Mean & 21.49 & 31.15 & 3.32 & 7.7 & 0.00 \\
\hline Maximum & 39.11 & 85.20 & 10.94 & & 0.00 \\
\hline Minimum & 9.50 & 5.51 & 0.00 & & 0.00 \\
\hline
\end{tabular}

Table 2. Meteorologist of the study area during the growth periods of quinoa plant 


\subsection{Crop Coefficient and Water Requirements of Quinoa Plant}

The value of water requirements monthly can be calculate using the value of evapotranspiration per month depending on the data in Table 3 and the crop coefficient $(K c)$ per the same month from Figure 1 during growing stages of quinoa plant.

Table 3. Means of monthly reference evapotranspiration $(E T o)$ in the study rejoin

\begin{tabular}{llll}
\hline \multicolumn{4}{c}{ Evapotranspiration $/$ month $\left(\mathrm{m}^{3} / \mathrm{ha}\right)$} \\
\hline December & January & February & March \\
\hline 1000 & 1000 & 1200 & 1650 \\
\hline
\end{tabular}

The cultivation of quinoa plant was in the first of December and the crop coefficient $(\mathrm{Kc})$ for the first stage was 0.5 (during 21 days) and the second stage 0.60 (the number of days 25) and the third stage 1.00 (the number of days 40 ) and the fourth stage 0.25 (the number of days 21 ). It means that the survival of the crop in the soil is 107 days.

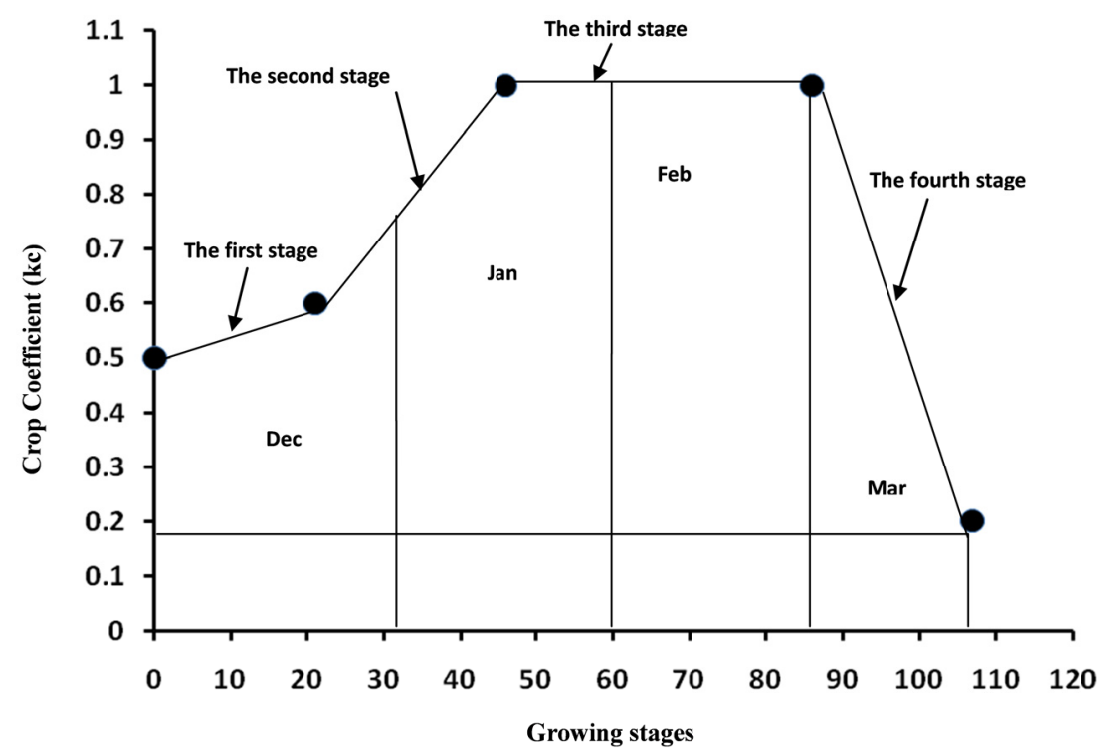

Figure 1. Crop coefficient $(\mathrm{kc})$ during growing stages of quinoa plant

The crop coefficient $(\mathrm{Kc})$ during all different growth stages determined as follow:

$>\quad$ Crop coefficient $(\mathrm{Kc})$ during 1 to 21 December $=0.5$ (during the first stage) $\times 21=10.5$

Crop coefficient $(\mathrm{Kc})$ during 21 to 30 December $=(0.5+0.6) / 2$ (the mean during the first and the second stage $) \times$ $9=4.95$

So, crop coefficient $(\mathrm{Kc})$ during December month $=(10.50+4.95) / 30=0.515$

From Table 3, the mean of evapotranspiration during December is $1000 \mathrm{~m}^{3} / \mathrm{ha}$. So, water requirements of quinoa plant $\left(\right.$ ET) during December month $=0.515 \times 1000=515 \mathrm{~m}^{3} / \mathrm{ha}$.

$>$ From Figure 1, the mean of crop coefficient $(\mathrm{Kc})$ during January month $=(0.72+1.00) / 2=0.86$ (during the second and the third stage) and the mean of evapotranspiration is $1000 \mathrm{~m}^{3} /$ ha (Table 3 ).

So, water requirements of quinoa plant (ET) during January month $=0.86 \times 1000=860 \mathrm{~m}^{3} / \mathrm{ha}$.

$>$ In this regard, the mean of crop coefficient $(\mathrm{Kc})$ during February month $=(1.00+0.90) / 2=0.95$ (Figure 1) and the mean of evapotranspiration is $1200 \mathrm{~m}^{3} /$ ha (Table 3 ).

So, water requirements of quinoa plant (ET) during February month $=0.95 \times 1200=1140 \mathrm{~m}^{3} / \mathrm{ha}$. 
$>$ In the same way, the mean of crop coefficient $(\mathrm{Kc})$ during 1 to 17 March $=(0.90+0.20) / 2=0.55$ (Figure 1$)$ and the mean of evapotranspiration is $1650 \mathrm{~m}^{3} /$ ha (Table 3 ).

So, water requirements of quinoa plant $\left(\right.$ ET) during February month $=0.55 \times(17 / 30) \times 1650=514.25 \mathrm{~m}^{3} / \mathrm{ha}$.

Consequently, the total of water requirements of quinoa plant (ET) during the period from 30 December to 17 March $=515+860+1140+514.25=3029.25 \mathrm{~m}^{3} /$ ha. This amount of water requirements of quinoa plant less than that of wheat crop.The calculation of the amount of depleting water in the flood irrigation using the measuring tools showed that the amount of consumed water was $6921 \mathrm{~m}^{3} \mathrm{ha}^{-1}$ for the first treatment (once every four days), $3955 \mathrm{~m}^{3} \mathrm{ha}^{-1}$ (once every week) and $1846 \mathrm{~m}^{3} \mathrm{ha}^{-1}$ (once every two weeks) and Table 4 shows the amount of loss water comparison with the water requirements during growth stages of the quinoa crop. The amount of available water using Equation 3 and under Al-Ahssa rejoin conditions was $6310 \mathrm{~m}^{3} \mathrm{ha}^{-1}$.

Table 4. The comparison between the amounts of depleted irrigation water and water requirement for quinoa crop

\begin{tabular}{llll}
\hline Treatments & $\begin{array}{l}\text { Quantity of used water } \\
\left(\mathrm{m}^{3} \mathrm{ha}^{-1}\right)\end{array}$ & $\begin{array}{l}\text { The ratio between the quantity } \\
\text { of used water and calculated } \\
\text { water requirement* }\end{array}$ & $\begin{array}{l}\text { The ratio between the quantity } \\
\text { of used water and the quantity } \\
\text { of available water** }\end{array}$ \\
\hline $\mathrm{T} 1$ & 6921 & 2.28 & 1.10 \\
$\mathrm{~T} 2$ & 3955 & 1.31 & 0.63 \\
$\mathrm{~T} 3$ & 1846 & 0.61 & 0.30
\end{tabular}

Note. $*$ The calculated water requirement of quinoa plant $=3029.25 \mathrm{~m}^{3} \mathrm{ha}^{-1} ; * *$ The quantity of available water $=$ $6310 \mathrm{~m}^{3} \mathrm{ha}^{-1}$.

\subsection{Effect of Treatments on Some Traits and Correlation Coefficient}

Table 5 demonstrates the effect of water deficit stress, using three levels of drought, on the yield and its components, including grain yield, straw yield, harvest index, number of grains $/ \mathrm{m}^{2} \times 10^{3}$. The results showed non significant effect of different treatments on the averages of the previous traits of the quinoa plants under study. T2 treatment showed the highest averages followed by T3 treatment in all traits except the number of grains $/ \mathrm{m}^{2}$.

Table 5. Effect irrigation treatments on yield and its some components

\begin{tabular}{|c|c|c|c|c|}
\hline Treatments & $\begin{array}{l}\text { Grain yield } \\
\text { (megagram/hectare) }\end{array}$ & $\begin{array}{l}\text { Straw yield } \\
\text { (megagram/hectare) }\end{array}$ & Harvest index & Number of grains $/ \mathrm{m}^{2} \times 10^{3}$ \\
\hline $\mathrm{T} 1$ & $\mathrm{~b}_{2.00}$ & $\mathrm{a}_{3.00}$ & ${ }^{\mathrm{b}} 0.67$ & ${ }^{\mathrm{a}} 60.3$ \\
\hline $\mathrm{T} 2$ & ${ }^{\mathrm{a}} 2.50$ & a 3.09 & ${ }^{\mathrm{a}} 0.81$ & a 66.9 \\
\hline $\mathrm{T} 3$ & ${ }^{b} 2.15$ & a 3.22 & ${ }^{\mathrm{b}} 0.67$ & ${ }^{\mathrm{a}} 55.3$ \\
\hline $\operatorname{LSD}_{(0.05)}$ & 0.39 & 0.62 & 0.16 & 13.91 \\
\hline CV \% & 10.2 & 11.57 & 13.11 & 13.2 \\
\hline
\end{tabular}

Note. Means with different superscripts between three treatments in the same column are significantly different at $p<0.05$.

Simple correlation coefficients among quantity of used water and some traits (number of grains, grain yield, straw yield and harvest index) were estimated in Table 6 and the results clearly indicate that, correlation coefficient was negative with the most traits and low with the number of grain $(0.34)$ under overall studied treatments conditions which confirms that quinoa is a plant that needs limited amounts of irrigation water. On the other hand there was positive strong correlation between the harvest index and grain yield (0.92). 
Table 6. Correlation coefficients values between some studied traits over all drought levels

\begin{tabular}{lllll}
\hline Trait & Quantity of used water & Number of grains & Grain yield & Straw yield \\
\hline Number of grain & $0.34^{* *}$ & & & \\
Grain yield & $-0.38^{* *}$ & $0.74^{* *}$ & & \\
Straw yield & $-0.98^{* *}$ & $-0.52^{* *}$ & $0.19^{*}$ & \\
Harvest index & $-0.71^{* *}$ & $0.43^{* *}$ & $0.92^{* *}$ & $0.55^{* *}$ \\
\hline
\end{tabular}

Note. ${ }^{*}$ and ${ }^{* *}$ : significant at the 0.05 and 0.01 level of probability, respectively.

\subsection{The Effect of Irrigation Treatments on Some Properties of Soil Chemical}

Table 7 shows that the soil $\mathrm{pH}$ values not affected significantly with irrigation treatments and arranged from mean values of 7.5 (T1) to mean values of 7.8 (T3) and the values are less whenever irrigation periods increase.

The results showed that the concentration of ammonia $\left(\mathrm{NH}_{4}-\mathrm{N}\right)$ in the soil under $\mathrm{T} 3$ treatment was significantly higher than the other soils. Also, It is clear from the results in Table 8 that moisture stress treatment (T3) increase the $\mathrm{NO}_{3}-\mathrm{N}$ significantly compared with the other soils $(\mathrm{T} 1, \mathrm{~T} 2)$ and the values of phosphorus, potassium and magnesium available behaved the same trend. While, there was a significant increase in the micro elements of the plant ( $\mathrm{Fe}, \mathrm{Mn}, \mathrm{Zn}, \mathrm{Cu})$ with decreasing of water stress.

Table 7. Effect of Irrigation intervals treatments on electrical conductivity EC, $\mathrm{pH}$ and elemental composition of the soil after harvesting of quinoa crop

\begin{tabular}{llllll}
\hline \multirow{2}{*}{ Traits } & \multicolumn{3}{c}{ Treatments $(\mathrm{kg} \mathrm{N} / \mathrm{ha})$} & \multirow{2}{*}{ LSD $_{(0.05)}$} & \multirow{2}{*}{ C.V (\%) } \\
\cline { 2 - 5 } $\mathrm{EC}, \mathrm{mS} \mathrm{m}^{-1}$ & $\mathrm{~T} 1$ & $\mathrm{~T} 2$ & $3.42^{\mathrm{a}}$ & 0.395 & 10.75 \\
$\mathrm{pH}$ & $2.25^{\mathrm{c}}$ & $2.99^{\mathrm{b}}$ & $7.80^{\mathrm{a}}$ & 0.98 & 10.02 \\
$\mathrm{NH}_{4}-\mathrm{N}, \%$ & $7.50^{\mathrm{a}}$ & $7.70^{\mathrm{a}}$ & $8.90^{\mathrm{a}}$ & 0.76 & 8.88 \\
$\mathrm{NO}_{3}-\mathrm{N}, \%$ & $4.90^{\mathrm{b}}$ & $6.50^{\mathrm{ab}}$ & $40.40^{\mathrm{a}}$ & 2.71 & 9.01 \\
$\mathrm{P}_{\mathrm{NaHCO}}, \mathrm{ppm}$ & $10.10^{\mathrm{c}}$ & $20.60^{\mathrm{b}}$ & $5.85^{\mathrm{a}}$ & 1.20 & 15.29 \\
$\mathrm{~K}-\mathrm{HN}_{4} \mathrm{OAC}, \mathrm{ppm}$ & $6.65^{\mathrm{a}}$ & $6.00^{\mathrm{a}}$ & $305^{\mathrm{a}}$ & 41.19 & 9.91 \\
$\mathrm{Ca}-\mathrm{HN}_{4} \mathrm{OAC}, \mathrm{ppm}$ & $362^{\mathrm{b}}$ & $315^{\mathrm{b}}$ & $2215^{\mathrm{a}}$ & 332.64 & 12.23 \\
$\mathrm{Mg}-\mathrm{HN}{ }_{4} \mathrm{OAC}, \mathrm{ppm}$ & $2100^{\mathrm{a}}$ & $2110^{\mathrm{a}}$ & $110^{\mathrm{a}}$ & 21.29 & 16.12 \\
$\mathrm{Fe}-\mathrm{DTPA}, \mathrm{ppm}$ & $100^{\mathrm{a}}$ & $102^{\mathrm{a}}$ & $25.40^{\mathrm{b}}$ & 13.41 & 10.15 \\
$\mathrm{Mn}-\mathrm{DTPA}, \mathrm{ppm}$ & $39.80^{\mathrm{a}}$ & $31.60^{\mathrm{ab}}$ & $4.10^{\mathrm{c}}$ & 0.53 & 6.25 \\
Zn-DTPA, ppm & $8.50^{\mathrm{a}}$ & $7.60^{\mathrm{b}}$ & $2.10^{\mathrm{c}}$ & 0.39 & 12.00 \\
Cu-DTPA, ppm & $3.30^{\mathrm{a}}$ & $2.30^{\mathrm{b}}$ & $2.10^{\mathrm{c}}$ & 0.34 & 12.10 \\
\hline
\end{tabular}

Note. Means in each row for each parameter followed by the same letter are not significantly different according to least significant differences at 0.05 level of significant $\left(\operatorname{LSD}_{(0.05)}\right)$.

\section{Discussion}

\subsection{Water Requirements of Quinoa Plant}

The amount of water requirements of quinoa plant less than that of wheat crop where, Al-Zeid et al. (1988) stated that, water requirements of cultivated wheat in the study rejoin in Al-Hassa was $4736 \mathrm{~m}^{3} \mathrm{ha}^{-1}$. Also Rayan et al. (2000) reported that, water requirements of wheat crop ranged from 3560.86 to $4329.37 \mathrm{~m}^{3} / \mathrm{ha}$ in the new reclamation areas of Upper Egypt under different sowing dates. In the same manner, Greets et al. (2008) stated that the amount of consumed water was $140-250 \mathrm{~mm}$ in the case of complete irrigation, while in the case of deficit irrigation ranged between 30-125 mm in the study which carried out in Bolivia. Accordingly, we can discuss the introduction of quinoa cultivation next to wheat cultivation in the winter season in drought-affected areas such as Saudi Arabia or in some rejoins as Egypt which exposed to negative effects caused by the climatic changes and political conflicts on water of the River Nile.

\subsection{Effect of Treatments on Some Traits and Correlation Coefficient}

The results in Table 5 has been compatible with what found Greets et al. (2008) when comparing full irrigation with deficit irrigation. Suffice to say, it is clear from this brief over view that, water requirements to quinoa plant 
are low and it can grow under deficit of water without effect on yield. The previous studies indicated that the quinoa plant has several drought resistance mechanisms; drought escape (as a prolongation of the growth cycle in response to drought in the early vegetative stages and as early maturity in response to drought in later growth stage), tolerance (through high tissue elasticity and low osmotic potential) and avoidance (through its deep dense root system, reduction of its leaf area, vesicular glands, small and thick walled cells preserving turgor even and dynamic stomatal behaviour) (Jensen et al., 2000; Jacobsen et al., 2003b), which makes it suitable option for cultivation in the scarce water resources and which is prominent feature in the study region. Which confirms that the plant quinoa from plants that are resistant to various stress such as salinity, cold air, high solar radiation, frost and different $\mathrm{pH}$ in the soil (Jacobsen et al., 1998). Also, quinoa plant can grow in arid and semi-arid regions and low lands (Jacobsen et al., 1994). While both the Gallardo and Gonzalez (1992) explained that the soil moisture level plays an important role in determining the time and the growth rate of quinoa seeds and seedlings. Mhada et al. (2014), studied the correlation coefficients between grain yield and the reaction to downy mildew with the other traits in quinoa plant. In the same manner, they found that correlations values ranged between 0.09 and 0.76 as positive values and -0.22 as a negative value of studied traits with grain yield.

\subsection{The Effect of Irrigation Treatments on Some Properties of Soil Chemical}

The values of electric conductivity (EC) are less whenever irrigation intervals decrease. According to $\mathrm{pH}$, it was observed that with the decrease in the amount of irrigation water, the value of $\mathrm{pH}$ increased, but the increase was non significant and generally quinoa plant can grow with $\mathrm{pH}$ ranges of 4.5:9 (Geerts et al., 2008). In the same manner, elements composition differed where recorded the highest significant differentials in $\mathrm{NO}_{3}, \mathrm{Mn}, \mathrm{Zn}$ and $\mathrm{Cu}$ ions while the differential responses in the amount of irrigation water were non significant in $\mathrm{P}, \mathrm{Ca}$, and $\mathrm{Mg}$ ions. and probably due to the effect of irrigation water on melting the amount of calcium carbonate and release carbon dioxide which reacts with the irrigation water to produce carbonic acid, which has an acidic effect on the soil and components of the soil solution around the plant roots (Pocknee \& Summer, 1997). In this context, Amtmann and Blatt (2009) stated that, the environmental factors such as drought may cause nutrient deficiencies, even in fertilized fields, as the physiochemical properties of the soil can lead to a reduced mobility and absorbance of individual nutrients. Generally, quinoa plant has the potential to grow with fewer inputs, water and tolerate a variety of biotic and a biotic stresses as compared to common cereals (Basra et al., 2014).

The cultivation of drought-tolerant plants associated with high nutrient-use efficiency such as quinoa plant may help on the mitigation of this problem.

\section{References}

Allen, R. G., Pereira, L. S., Raes, D., \& Smith, M. (1998). Crop evapotranspiration. Guidelines for computing crop water requirements. Irrigation and Drainage Paper 56 (p. 300). Food and Agric. Organization of the United Nations, Rome, Italy.

Al-Zeid, A. A., Quintana, E. U., Abu Khate, M. I., Nimah, M. N., Al-Samerai, F. H., \& Bashour, I. I. (1988). Guide for crop water requirements in the Kingdom of Saudi Arabia (p. 106). Department of Agricultural Developments, Ministry of Agriculture and Water.

Amtmann, A., \& Blatt, M. R. (2009). Regulation of macronutrient transport. New Phytologist, 181, 35-52. https://doi.org/10.1111/j.1469-8137.2008.02666.x

Badran, A. E., Esraa, A. M., El-Sherebeny, \& Salama, Y. A. (2015). Performance of some Alfalfa cultivars under salinity stress conditions. Journal of Agricultural Science, 7(10), 281-290. https://doi.org/10.5539/ jas.v7n10p281

Basra, S. M. A., Iqbal, S., \& Afzal, I. (2014). Evaluating the response of nitrogen application on growth, development and yield of quinoa genotypes. International Journal of Agriculture \& Biology, 16(5), 886-892.

Bilbao Lopez, M., Espindola, G., \& Peric Alarcon, Y. (2006). Semilla basica por'seleccion masal estratificada en ocho variedades de quinua (Chenopodium quinoa Willd.). In C. Del Castillo, M. Garcia, J. J. Vacher, T. Winkel (Eds.), Compendio de Resumenes de Tesis de Grado e Investigaciones realizadas en Quinua, Canahua, Amarantho y Papa en la Facultad de Agronomia de la UMSA entre 1991 y 2006 (p. 22). Facultad de Agronomia, UMSA-IRD, Francia-QuinAgua, VLIR \& KULeuven, Belgica, La Paz, Bolivia.

Black, C. A. (Ed.). (1965). Methods of soil analysis (Part I). American Society of Agronomy, USA.

Chai, C. L., Li, S. H., \& Xu, Y. C. (2001). Carbohydrate metabolism in peach leaves during water stress and after stress relief. Plant Physiol. Commun., 37, 495-498. 
Choukr-Allah, R., Rao, N. K., Hirich, A., Shahid, M., Alshankiti, A., Toderich, K., Gill, S., \& Butt, K. U. R. (2016). Quinoa for Marginal Environments: Toward Future Food and Nutritional Security in MENA and Central Asia Regions. Front. Plant Sci., 7, 346. https://doi.org/10.3389/fpls.2016.00346

English, M. (1990). Deficit irrigation. I. Analytical framework. J. Irrig. Drain E. ASCE, 116, $399-412$. https://doi.org/10.1061/(ASCE)0733-9437(1990)116:3(399)

Gallardo, M. G., \& Gonzalez, J. A. (1992). Efecto de algunos factor esambiental essobre la germinación de Chenopodium quinoa W. y susposibilidades de cultivoenalgunas zonas de la Provincia de Tucumán (Argentina). LILLOA, XXXVIII, 55-64.

Garcia, M., Raes, D., \& Jacobsen, S. E. (2003). Evapotranspiration analysis and irrigation requirements of quinoa (Chenopodium quinoa) in the Bolivian highlands. Agric. Water Manage., 60, 119-134. https://doi.org/10.1016/S0378-3774(02)00162-2

Geerts, S., Raes, D., Garcia, M., Del Castillo, C., \& Buytaert, W. (2006). Agro-climatic suitability mapping for crop production in the Bolivian Altiplano: A case study for quinoa. Agric. Forest Meteorol., 139, $399-412$. https://doi.org/10.1016/j.agrformet.2006.08.018

Geerts, S., Raes, D., Garcia, M., Vacher, J., Mamanib, R., Mendoza, J., ... Taboada, C. (2008). Introducing deficit irrigation to stabilize yields of quinoa (Chenopodium quinoa Willd.). Europ. J. Agronomy, 28, 427-436. https://doi.org/10.1016/j.eja.2007.11.008

Henriques, F. S. (2008). Photosynthetic characteristics of light sensitive, chlorophyll-deficient leaves from sectorially chimeric stinging-nettle. Bot. Stud., 49, 235-241.

Howell, T. (2001). Enhancing water use efficiency in irrigated agriculture. Agron. J., 93, $281-289$. https://doi.org/10.2134/agronj2001.932281x

Jacobsen, S. E., Jørgensen, I., \& Stølen, O. (1994). Cultivation of quinoa (Chenopodium quinoa) under temperate climatic conditions in Denmark. J. Agric. Sci., 122, 47-52. https://doi.org/10.1017/S002185 9600065783

Jacobsen, S. E., Mujica, A., \& Ortiz, R. (2003b). The global potential for quinoa and other Andean crops. Food Rev. Int., 19, 139-148. https://doi.org/10.1081/FRI-120018880

Jacobsen, S. E., Nunez, N., Spehar, C. R., \& Jensen, C. R. (1998). Quinoa: Apotential drought resistant crop for the Brazilian savannah. Proc. Ofthe Int. Conf. on Sustainable Agriculture in Tropical and SubtropicalHighlands with Special Reference to Latin America (SATHLA) [CDROM]. INT, Rio de Janeiro.

Jensen, C. R., Jacobsen, S. E., Andersen, M. N., \& Núńez, S. D. (2000). Leaf gas exchange and water relation characteristics of field quinoa (Chenopodium quinoa Willd.) during soil drying. Eur. J. Agron., 13, 11-25. https://doi.org/10.1016/S1161-0301(00)00055-1

Kijne, J. W., Barker, R., \& Molden, D. (2003). Improving water productivity in agriculture: editor's overview. In J. W. Kijne, R. Barker \& D. Molden (Eds.), Water Productivity in Agriculture: Limits and Opportunities for Improvement (pp. xi-xix). International Water Management Institute, Colombo, Sri Lanka. https://doi.org/10.1079/9780851996691.0000

Lin, K. H., Chao, P. Y., Yang, C. M., Cheng, W. C., Lo, H. F., \& Chang, T. R. (2006). The effects of flooding and drought stresses on the antioxidant constituents in sweet potato leaves. Bot. Stud., 47, 417-426.

McDonald, A. J. S., \& Davis, W. J. (1996). Keeping in touch: Responses of the whole plant to deficits in water and nitrogen supply. Adv. Bot. Res., 22, 229-300. https://doi.org/10.1016/S0065-2296(08)60059-2

Mhada, M., Jellen, E. N., Jacobsen, S. E., \& Benlhabib, O. (2014). Diversity analysis of a Quinoa (Chenopodium quinoa Willd.) germplasm during two seasons. International Journal of Biological, Biomolecular, Agricultural, Food and Biotechnological Engineering, 8(3), 273-276.

Page, A. L., Miller, R. H., \& Keeney, D. R. (Eds.). (1982). Methods of Soil Analysis: Part 2, Chemical and Microbiological Properties. Gronomy Series No 9. American Society of Agronomy, Madison, WI.

Pocknee, S., \& Sumner, A. (1997). Cation and nitrogen contents of each of organic matter determines its liming potential. Soil Sci. Soc. Am. J., 61, 86-96. https://doi.org/10.2136/sssaj1997.03615995006100010014x

Raes, D., Jacobsen, S. E., \& Magalí, G. (2003). Evapotranspiration analysis and irrigation requirements of quinoa (Chenopodium quinoa) in the Bolivian highlands. Agricultural Water Management, 119-134. 
Rayan, A. A., El-Marsafawy, A. S., Ainer, N. G., \& Soliman, S. E. (2000). Scheduling irrigation of wheat crop in Upper Egypt under different sowing dates. Egypt. J. ARP. Sci., 15(1), 56-70.

Razzaghi, F., Plauborg, F., Jacobsen, S., Jensen, C. R., \& Andersen, M. N. (2012). Effect of nitrogen and water availability of three soil types on yield, radiation use efficiency and evapotranspiration in field-grown quinoa. Agricultural Water Management, 109, 20-29. https://doi.org/10.1016/j.agwat.2012.02.002

Singh, R. K., \& Chaudhary, B. D. (1995). Biometrical Methods in Quantitative Genetic Analysis (pp. 215-218). Kalyani Publishers, New Delhi.

Smith, M. (2000). The application of climatic data for planning and management of sustainable rainfed and irrigated crop production. Agric. Forest Meteorol., 103, 99-108. https://doi.org/10.1016/S0168-1923(00) 00121-0

Steel, R. G., \& Torrie, J. H. (1998). Principles and procedures of statistic (2nd ed., p. 633). McGraw-Hill Book Co, New York, NY.

Zhang, H., \& Oweis, T. (1999). Water-yield relations and optimal irrigation scheduling of wheat in the Mediterranean region. Agric. Water Manage., 38, 195-211. https://doi.org/10.1016/S0378-3774(98)00069-9

\section{Copyrights}

Copyright for this article is retained by the author(s), with first publication rights granted to the journal.

This is an open-access article distributed under the terms and conditions of the Creative Commons Attribution license (http://creativecommons.org/licenses/by/4.0/). 